\title{
PROFIL KETERAMPILAN BERTANYA PESERTA DIDIK PADA PEMBELAJARAN FISIKA KELAS XI MIPA SMAN 2 MAJENE
}

\author{
Arie Arma Arsyad ${ }^{1, \mathrm{a}}$, Hardi Hamzah ${ }^{2, \mathrm{~b}}$, Lis Nuraisa ${ }^{3, \mathrm{c}}$ \\ 1,2,3 Program Studi Pendidikan Fisika, Fakultas Keguruan dan Ilmu Pendidikan, Universitas Sulawesi Barat \\ e-mail: $\underline{\text { ariearmaarsyad@unm.ac.id, }}$, $\underline{\text { hardi@unsulbar.ac.id, }}, \underline{ }$ lisnuraisa@unsulbar.ac.id
}

\begin{abstract}
Abstrak
Tujuan Penelitian ini adalah untuk mengetahui keterampilan bertanya dan kualitas pertanyaan peserta didik pada pembelajaran fisika kelas XI MIPA SMA Negeri 2 Majene. Subyek dalam penelitian ini adalah seluruh peserta didik kelas XI MIPA yang berjumlah 137 peserta didik. Data kualitatif berupa keterampilan bertanya dan kualitas pertanyaan yang diperoleh melalui observasi dan dianalisis dengan menghitung persentase dan diinterpretasikan ke dalam tabel kriteria serta diperkuat dengan hasil dokumentasi dan wawancara. Hasil penelitian menunjukan keterampilan bertanya peserta didik kelas reguler berkategori "rendah". Sedangkan, kelas unggulan berkategori "sedang". Kualitas pertanyaan peserta didik kelas reguler dan kelas unggulan berkategori "rendah". Pada kelas reguler peserta didik laki-laki lebih banyak mengajukan pertanyaan dibandingkan peserta didik perempuan. Sedangkan, untuk kelas unggulan peserta didik perempuan lebih banyak mengajukan pertanyaan dibandingkan peserta didik laki-laki.
\end{abstract}

Kata kunci: keterampilan bertanya, kualitas pertanyaan, taksonomi bloom

\section{PROFILE SKILLS ASKING STUDENTS IN PHYSICS LEARNING CLASS XI MIPA SMAN 2 MAJENE}

\begin{abstract}
The purpose of this research is to know the questioning skills and quality of students' questions in learning physics at the XI MIPA class of SMA Negeri 2 Majene. The subjects in this study were all students of class XI MIPA, totaling 137 students. Qualitative data in the form of questioning skills and the quality of questions obtained through observation and analyzed by calculating percentages and interpreted into the criteria table and strengthened by the results of documentation and interviews. The results showed the questioning skills of regular class students were categorized as "low". Meanwhile, the superior class is in the category of 'medium'. The quality of questions of students in both regular and superior classes is categorized as "low". In regular classes, male students ask more questions than female students. Whereas, for superior classes female students asked more questions than male students.
\end{abstract}

Keywords: questioning skills, quality of questions, bloom taxonomy 


\section{PENDAHULUAN}

Bertanya merupakan suatu kegiatan yang sering terjadi dalam kehidupan seharihari. Begitu pula dalam kegiatan belajar mengajar, bertanya termasuk hal yang sudah lazim. Bertanya adalah salah satu fungsi pokok bahasa selain fungsi lain seperti menyatakan pendapat, perasaan, mengajukan alasan, mempertegas pendapat dan sebagainya [1]. Bertanya dianggap penting terjadi dalam pembelajaran. Hal ini dapat menunjukkan terjadinya proses berpikir pada diri peserta didik serta dapat memaksimalkan cangkupan tujuan pembelajaran. Bertanya memiliki peranan penting dalam pembelajaran. Dengan bertanya, peserta didik menjadi aktif dalam mengikuti pembelajaran. Keaktifan peserta didik dalam bertanya sangat diperlukan untuk mengetahui tingkat pemahaman peserta didik dalam menerima materi pembelajaran. Dalam pembelajaran ilmiah khususnya, peserta didik dituntut aktif menemukan konsep-konsep yang telah dipelajari.

Saat ini, peserta didik tidak terbiasa mengajukan pertanyaan, padahal dengan mengajukan pertanyaan dapat meningkatkan kemampuan peserta didik untuk menemukan gagasan, minat, dan rasa ingin tahu. Hal ini terjadi karena diakibatkan oleh beberapa hal misalnya peserta didik tidak menyukai materi, kurangnya motivasi belajar peserta didik. Komponen yang mempengaruhi proses belajar yaitu minat, metode pembelajaran, sumber belajar, sarana dan prasarana. Terlihat dari beberapa penelitian yang dilaksanakan di beberapa tempat diantaranya: Hasil penelitian Johan, dkk. 2016 menunjukkan bahwa sebanyak 66,66\% guru mengalami kendala dalam menerapkan model pembelajaran, semua guru menyatakan peserta didik cenderung tidak bertanya dalam pembelajaran [2]. Penelitian Widodo tahun 2006 Tentang profil pertanyaan guru dan siswa dalam pembelajaran sains, diperoleh data bahwa kemampuan bertanya siswa masih berada pada kategori rendah [3]. Hal ini sejalan dengan penelitian dilakukan oleh Farqiyatur tahun 2017, Tentang kemampuan bertanya siswa kelas X SMA Swasta Kota Batu Pada Pelajaran Biologi, diketahui bahwa 23,30\% siswa SMA swasta Kota Batu mengajukan pertanyaan dengan kualitas $100 \%$ tergolong Low Order Thinking Skills (LOTS) [4].

Berdasarkan hasil pengamatan peneliti di SMA Negeri 2 Majene bahwa keterampilan bertanya peserta didik masih rendah. Fenomena yang diamati dalam pembelajaran fisika diantaranya: tidak semua peserta didik aktif bertanya, hanya peserta didik tertentu yang mengajukan pertanyaan, bila peserta didik diberikan kesempatan untuk bertanya, beberapa sudah memanfaatkan namun masih ada beberapa peserta didik yang masih pasif dan ragu. Hal ini mengindikasikan bahwa keterampilan bertanya peserta didik masih kurang. Seperti hasil pengamatan di kelas XI MIPA, hanya 1 peserta didik yang mengajukan pertanyaan. Bahkan terdapat kelas dimana tidak ada peserta didik yang mengajukan pertanyaan dalam satu pertemuan. Untuk menguatkan kesimpulan dari hasil observasi di atas, penelitian tertarik untuk melakukan penelitian lebih lanjut dengan judul Profil keterampilan bertanya peserta didik pada pembelajaran fisika Kelas XI MIPA SMA Negeri 2 Majene Tahun 2019. 


\section{METODE}

\section{Jenis Penelitian}

Penelitian ini adalah penelitian kualitatif bersifat deskriptif dengan jenis penelitian studi kasus.

\section{Waktu dan Tempat Penelitian}

Penelitian ini dilaksanakan di SMA Negeri 2 Majene Beralamat di jalan Chairil Anwar No.3 kab. Majene prov. Sulawesi barat. Penelitian ini akan dilaksanakan pada semester ganjil tahun ajaran 2019.

\section{Subjek Penelitian}

Subyek dalam penelitian ini adalah seluruh peserta didik kelas XI MIPA SMA Negeri 2 Majene tahun ajaran 2018/2019 dengan jumlah keseluruhan 137. Kelas XI MIPA 1-4 merupakan kelas reguler sedangkan untuk kelas XI MIPA 5 merupakan kelas unggulan.

\section{Prosedur.}

\section{Tahap persiapan}

a. Membuat surat izin penelitian

b. Mengadakan observasi ke sekolah tempat diadakannya penelitian, untuk mendapatkan informasi tentang jumlah siswa yang menjadi subjek penelitian.

c. Mempersiapkan instrumen yang diperlukan dalam penelitian, yaitu lembar observasi keterampilan bertanya peserta didik.

\section{Tahap Pelaksanaan}

Observasi keterampilan bertanya peserta didik pada pembelajaran fisika dilakukan dengan pengamatan langsung.

\section{Tahap akhir}

Pengelolaan data hasil observasi keterampilan bertanya.

\section{Teknik Pengumpulan Data}

Teknik pengumpulan data dilakukan dengan menggunakan observasi, dokumentasi dan wawancara. Lembar observasi digunakan untuk pengamatan secara langsung bagaimana keterampilan bertanya dan kualitas bertanya peserta didik berdasarkan gender yang diajukan selama proses pembelajaran fisika. Metode dokumentasi dilakukan dengan mengambil gambar dan merekam hasil wawancara dan video saat proses pembelajaran fisika berlangsung. Metode wawancara dilakukan untuk mengetahui kesulitan-kesulitan peserta didik selama proses pembelajaran berlangsung.

Terdapat tiga jenis lembar observasi yang digunakan dalam penelitian yaitu lembar observasi keteramilan bertanya, lembar observasi profil keterampilan bertanya dan lembar observasi kualitas pertanyaan peserta didik (Tabel 1,2, dan 3).

Tabel.1 Lembar Observasi Keterampilan Bertanya Peserta Didik

\begin{tabular}{clll}
\hline No & \multicolumn{1}{c}{ Pertanyaan } & Ya & Tidak \\
\hline 1 & Peserta didik mengajukan pertanyaan dengan materi & & \\
& yang disampaikan selama pembelajaran \\
\hline 2 & $\begin{array}{l}\text { Peserta didik mengajukan pertanyaan yang panjang } \\
\text { dan bertele-tele }\end{array}$ & \\
\hline 3 & Peserta didik bertanya karena tertarik dengan materi & \\
& pelajaran \\
\hline 4 & Peserta didik mengangkat tangan sebelum \\
\hline
\end{tabular}




\begin{tabular}{cl}
\hline & mengajukan pertanyaan \\
\hline 5 & $\begin{array}{l}\text { Selama satu jam pelajaran, tidak ada peserta didik } \\
\text { yang mengajukan pertanyaan }\end{array}$ \\
\hline 6 & Saat bertanya peserta didik menggunakan bahasa baku \\
\hline 7 & $\begin{array}{l}\text { Saat bertanya siswa menggunakan kata tanya } \\
(5 \mathrm{~W}+1 \mathrm{H})\end{array}$ \\
\hline 8 & $\begin{array}{l}\text { Peserta didik menggunakan volume suara yang keras } \\
\text { ketika bertanya }\end{array}$ \\
\hline 9 & $\begin{array}{l}\text { Peserta didik menunjukan keseriusan saat bertanya } \\
\text { (tidak tertawa) }\end{array}$ \\
\hline &
\end{tabular}

Tabel 1. Diisi dengan cara memberi tanda ceklis $(\sqrt{ })$ pada kolom ya atau tidak berdasarkan kesesuaian antara pernyataan pada tabel dengankeadaan sebenarnya di dalam kelas.

Tabel 2. Lembar Observasi Profil Keterampilan Bertanya Peserta Didik

Tanggal observasi

Model pembelajaran :

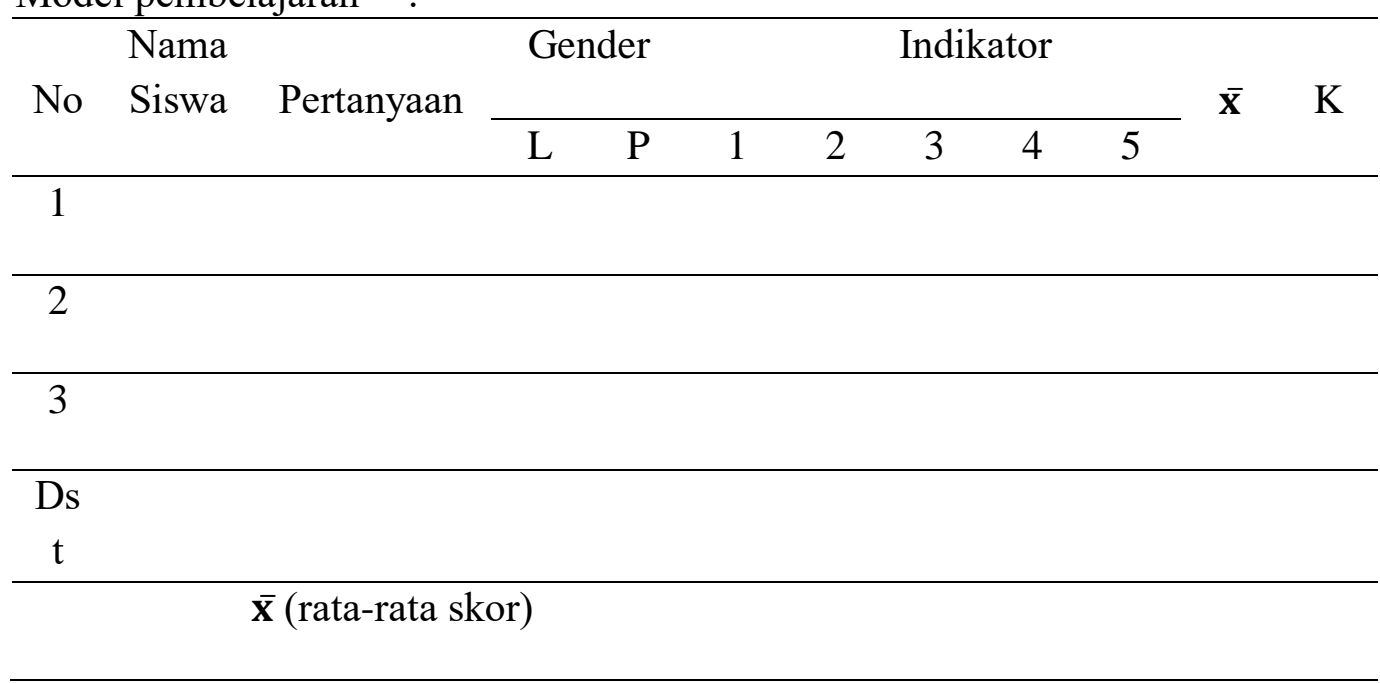

\section{Keterangan:}

$\mathrm{L}=$ Laki-laki, $\mathrm{P}=$ perempuan, $1=$ jumlah pertanyaan, $2=$ substansi,

3= bahasa, $4=$ kesopanan, $5=$ volume suara,

Cara pengisian lembar observasi di atas adalah dengan menulis nama peserta didik yang bertanya serta pertanyaan yang diajukan pada kolom yang tersedia. Kemudian memberi ceklis $(\sqrt{ })$ pada kolom gender dan skor 3,2,1 pada kolom indikator kemampuan bertanya dihitung rata-ratanya dan dikategorikan.

Tabel 3. Lembar Observasi Kualitas Pertanyaan Peserta Didik

\begin{tabular}{ccccc}
\hline & Siswa & Siswa & $\sum$ & $\sum$ \\
& Laki-laki & Perempuan & $\%$ & $\%$ \\
Tingkat ranah & $(\mathrm{N}=39)$ & $(\mathrm{N}=71)$ & & \\
\end{tabular}


kognitif

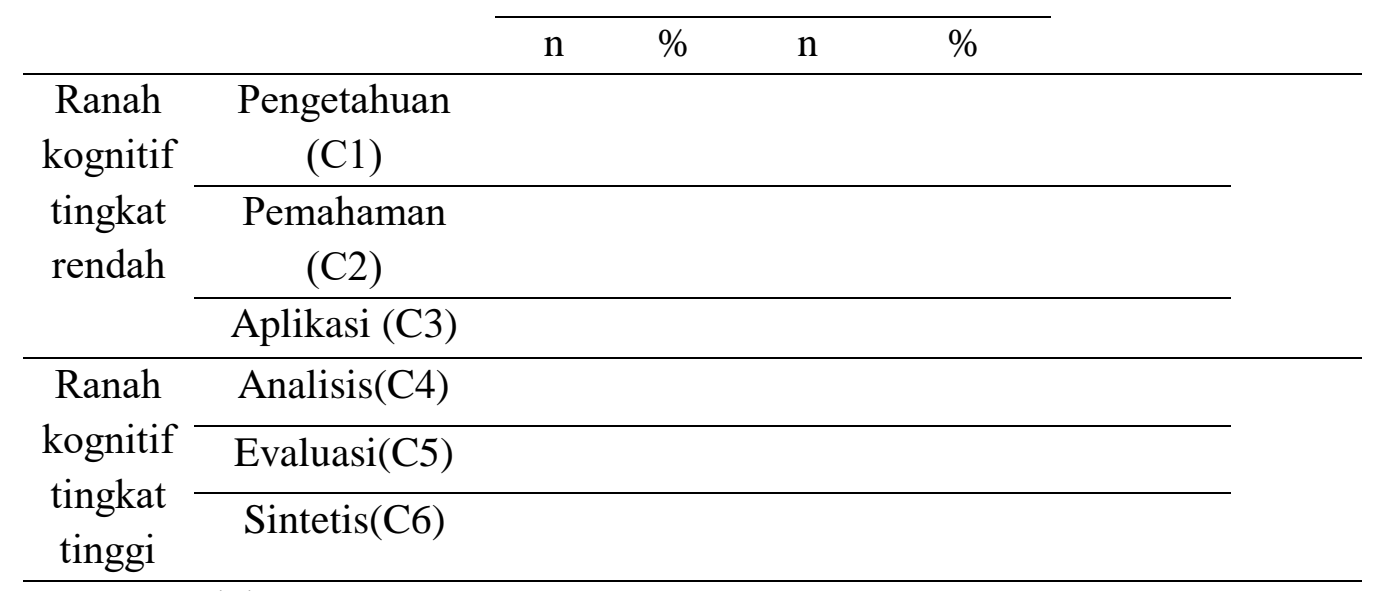

Jumlah pertanyaan

\section{Teknik Analisis Data}

a. Lembar observasi keterampilan bertanya peserta didik

1. Mengklasifikasikan skor 0 untuk jawaban yang tidak diharapkan, dan skor 1 untuk jawaban yang diharapkan.

2. Menghitung skor dalam bentuk persentase. Adapun rumus yang digunakan yaitu :

$$
\mathrm{K}=\frac{\mathrm{n}}{\mathrm{N}} \times 100 \%
$$

Keterangan:

$\mathrm{n}=$ nilai yang diperoleh observer

$\mathrm{N}=$ nilai yang semestinya diperoleh

$\mathrm{K}=$ persentase keterampilan bertanya peserta didik
3. Hasil perhitungan dalam bentuk persentase kemudian diinterpretasikan dalam tabel

b. Lembar Observasi Profil Keterampilan Bertanya Peserta Didik

1. Mengklasifikasikan skor 3, 2, 1 pada indikator profil keterampilan bertanya peserta didik sesuai dengan rubrik penilaian

2. Menghitung jumlah skor yang diperoleh dari masing-masing indikator profil keterampilan bertanya peserta didik kelas XI Mipa.

3. Membuat tabulasi data keterampilan bertanya peserta didik sebagai berikut:

Tabel 4. Tabulasi Data Profil Keterampilan Bertanya Peserta Didik

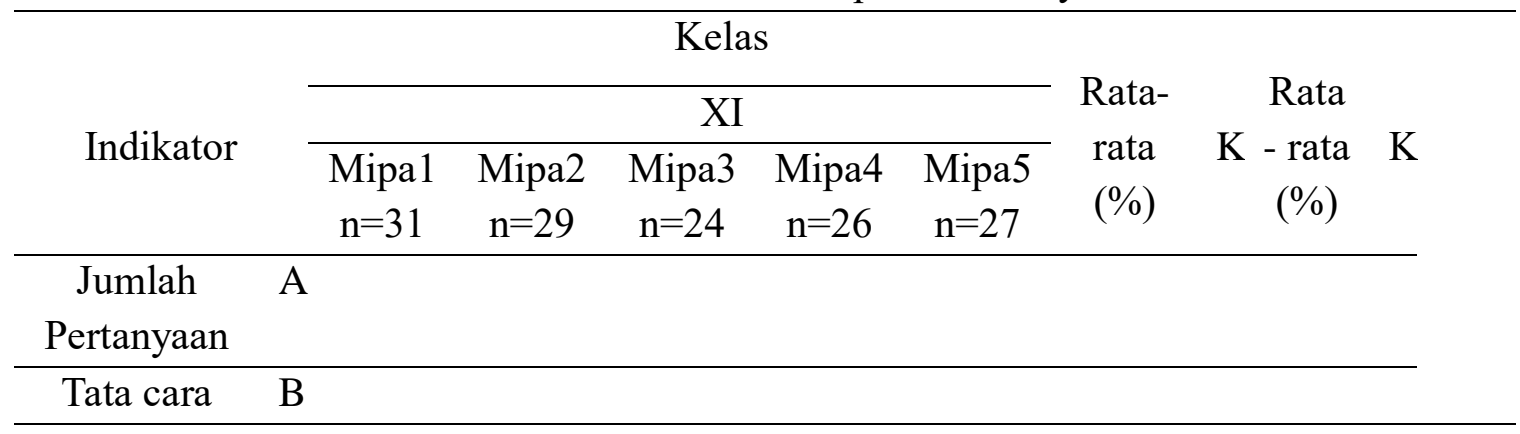




\begin{tabular}{ll}
\hline bertanya & $\mathrm{C}$ \\
\cline { 2 - 2 } $\mathrm{D}$ & $\mathrm{E}$
\end{tabular}

Rata - rata

Keterangan: $\mathrm{A}=$ Jumlah pertanyaan, $\mathrm{B}=$ Substansi pertanyaan, $\mathrm{C}=$ Bahasa,

$\mathrm{D}=$ Kesopanan, $\mathrm{E}=$ volume, $\mathrm{K}=$ kategori

Menghitung nilai rata-rata jumlah pertanyaan pada kelas XI, kemudian nilai rata-rata dipresentasikan menurut (Fitri Nuraini;2017) menggunakan rumus berikut:

Keterangan:

$$
\mathrm{K}=\frac{\mathrm{n}}{\mathrm{N}} \mathrm{X} 100 \%
$$

$\mathrm{n}=$ Jumlah pertanyaan peserta didik kelas XI

$\mathrm{N}=$ Jumlah peserta didik kelas XI

$\mathrm{K}=$ Persentase rata-rata jumlah pertanyaan peserta didik

4. Menghitung nilai rata-rata tiap indikator tata cara bertanya pada kelas XI, kemudian nilai rata-rata dipresentasekan menurut (Fitri Nuraini; 2017) menggunakan rumus berikut:

$$
\mathrm{K}=\frac{\mathrm{n}}{\mathrm{N}} \times 100 \%
$$

Keterangan:

$\mathrm{n}=$ Jumlah skor yang diperoleh peserta didik

$\mathrm{N}=$ Jumlah skor maksimal

$\mathrm{K}=$ Persentase rata-rata jumlah pertanyaan peserta didik

5. Menghitung nilai rata-rata persentase peserta didik kelas XI

6. Hasil perhitungan rata-rata dalam bentuk persentase diinterpretasikan dalam tabel 4.

c. Lembar observasi kualitas pertanyaan peserta didik

1. Menemukan peserta didik yang bertanya di dalam kelas dalam pertemuan ke-1,2,3 dan 4.
2. Menganalisis kualitas pertanyaan yang diajukan peserta didik dalam tiap pertemuan berdasarkan taksonomi bloom revisi.Menghitung nilai rata-rata dari jumlah pertanyaan peserta didik dalam empat pertemuan, kemudian dipersentasikan menurut (Fitri Nuraini;2017) menggunakan rumus sebagai berikut:

$$
\mathrm{K}=\frac{\mathrm{n}}{\mathrm{N}} \times 100 \%
$$

Keterangan:

$\mathrm{K}=$ Persentase rata-rata jumlah pertanyaan peserta didik.

$\mathrm{n}=$ rata-rata peserta didik yang bertanya pada pertemuan ke-1,2,3 dan 4

$\mathrm{N}=$ Jumlah seluruh peserta didik lakilaki/perempuan di dalam kelas

3. Menghitung total persentase rata-rata jumlah pertanyaan peserta didik baris ranah kognitif tingkat rendah $(\mathrm{C} 1-\mathrm{C} 3)$ dan menghitung total persentase ratarata pertanyaan peserta didik ranah kognitif tingkat tinggi (C4-C6) yang kemudian digunakan untuk mengetahui kualitas pertanyaan peserta didik.

4. Kualitas pertanyaan peserta didik berkategori "rendah" apabila pertanyaan kognitif tingkat rendah $(\mathrm{C} 1$ C3) lebih besar nilainya dibandingkan dengan pertanyaan kognitif tingkattinggi (C4-C6) atau sebaliknya kualitas pertanyaan peserta didik berkategori "tinggi apabila pertanyaan kognitif tingkat tinggilebih besar nilainya dibandingkan dengan pertanyaan kognitif tingkat rendah. 
5. Menghitung total persentase pada mengetahui kualitas pertanyaan peserta kolom peserta didik laki-laki dan peserta didik perempuan (tabel 3) untuk didik laki-laki dan peserta didik perempuan.

Tabel 5. Kriteria Keterampilan Bertanya Peserta Didik Dalam Pembelajaran Fisika Kelas XI Mipa.

\begin{tabular}{ccc} 
NO & $\begin{array}{c}\text { INTERVAL } \\
(\boldsymbol{\%})\end{array}$ & KRITERIA \\
$\mathbf{1}$ & $76<\% \leq 100$ & TINGGI \\
\hline $\mathbf{2}$ & $51<\% \leq 75$ & SEDANG \\
\hline $\mathbf{3}$ & $25<\% \leq 50$ & RENDAH \\
\hline $\mathbf{4}$ & $0<\% \leq 24$ & KURANG \\
\hline
\end{tabular}

\section{HASIL DAN DISKUSI}

Berdasarkan hasil penelitian yang dilakukan di SMA Negeri 2 Majene jumlah

Tabel 6. Jumlah Pertanyaan Peserta Didik Berdasarkan Gender.

\begin{tabular}{|c|c|c|c|c|c|c|c|c|c|}
\hline \multicolumn{10}{|c|}{ Kelas } \\
\hline \multirow{2}{*}{\multicolumn{2}{|c|}{$\begin{array}{c}\text { XI } \\
\text { Mipa } 1\end{array}$}} & \multirow{2}{*}{\multicolumn{2}{|c|}{$\begin{array}{c}\text { XI } \\
\text { Mipa } 2\end{array}$}} & \multirow{2}{*}{\multicolumn{2}{|c|}{$\begin{array}{c}\text { XI } \\
\text { Mipa } 3\end{array}$}} & \multirow{2}{*}{\multicolumn{2}{|c|}{$\begin{array}{c}\text { XI } \\
\text { Mipa } 4\end{array}$}} & \multirow{2}{*}{\multicolumn{2}{|c|}{$\begin{array}{c}\text { XI } \\
\text { Mipa } 5\end{array}$}} \\
\hline & & & & & & & & & \\
\hline $\mathrm{L}$ & $\mathrm{P}$ & $\mathrm{L}$ & $\mathrm{P}$ & $\mathrm{L}$ & $\mathrm{P}$ & $\mathrm{L}$ & $\mathrm{P}$ & $\mathrm{L}$ & $\mathrm{P}$ \\
\hline 1 & 0 & 3 & 1 & 0 & 0 & 1 & 1 & 4 & 9 \\
\hline
\end{tabular}

Keterangan:

$\mathrm{L}=$ Laki-laki

$\mathrm{P}=$ Perempuan

Berdasarkan hasil penelitian yang dilakukan di SMA Negeri Majene profil keterampilan bertanya peserta didik kelas XI MIPA 1,2,3,4 berkategori "Rendah" dengan pertanyaan peserta didik berdasarkan gender (Tabel.6).

Tabel 7. Lembar Observasi Profil Keterampilan Bertanya Kelas Reguler

\begin{tabular}{|c|c|c|c|c|c|c|c|c|}
\hline \multirow[t]{2}{*}{ Indikator } & & \multicolumn{4}{|c|}{ Kelas XI MIPA } & \multirow{2}{*}{$\begin{array}{c}\text { Rata- } \\
\text { rata } \\
(\%)\end{array}$} & \multirow[t]{2}{*}{$\mathbf{K}$} & \multirow{2}{*}{ Rata- $\quad K$} \\
\hline & & 1 & 2 & 3 & 4 & & & \\
\hline Jumlah & $\mathrm{A}$ & 3,22 & 13,79 & 0 & 11,5 & 7,13 & $\mathrm{~K}$ & 7,13 \\
\hline \multirow[t]{3}{*}{ Pertanyaan } & & & & & 3 & & & \\
\hline & B & 100 & 83,33 & 0 & 100 & 70,83 & $\mathrm{~S}$ & 60,93 \\
\hline & $\mathrm{C}$ & 66,6 & 58,33 & 0 & 100 & 56,25 & $\mathrm{~S}$ & \\
\hline
\end{tabular}




\begin{tabular}{|c|c|c|c|c|c|c|c|c|c|}
\hline \multirow{3}{*}{$\begin{array}{l}\text { Tata Cara } \\
\text { Bertanya }\end{array}$} & \multicolumn{3}{|c|}{7} & & & & & & \multirow[t]{3}{*}{$\mathrm{S}$} \\
\hline & $\mathrm{D}$ & $\begin{array}{c}66,6 \\
7\end{array}$ & 66,67 & 0 & 100 & 58,33 & $\mathrm{~S}$ & & \\
\hline & $\mathrm{E}$ & 100 & 66,67 & 0 & $\begin{array}{c}66,6 \\
7\end{array}$ & 58,33 & $S$ & & \\
\hline Rata - rata & & $\begin{array}{c}67,3 \\
1\end{array}$ & 57,75 & 0 & $\begin{array}{c}75,6 \\
4\end{array}$ & & & 34,03 & $\mathrm{R}$ \\
\hline
\end{tabular}

Tabel.12 Lembar Observasi Profil Keterampilan Bertanya Kelas Unggulan

\begin{tabular}{ccccccc}
\hline Indikator & $\begin{array}{c}\text { Kelas XI } \\
\text { MIPA 5 }\end{array}$ & Rata- rata (\%) & K & $\begin{array}{c}\text { Rata- rata } \\
\mathbf{( \% )}\end{array}$ & K \\
\hline $\begin{array}{c}\text { Jumlah } \\
\text { Pertanyaan }\end{array}$ & $\mathrm{A}$ & 48,14 & 48,14 & $\mathrm{~S}$ & 48,14 & $\mathrm{~S}$ \\
\hline $\begin{array}{c}\text { Tata Cara } \\
\text { Bertanya }\end{array}$ & $\mathrm{B}$ & 100 & 100 & $\mathrm{~T}$ & 84,02 & $\mathrm{~T}$ \\
\cline { 2 - 5 } & $\mathrm{C}$ & 94,44 & 94,44 & $\mathrm{~T}$ & & \\
\cline { 2 - 5 } & $\mathrm{D}$ & 77,78 & 77,78 & $\mathrm{~T}$ & & \\
\cline { 2 - 5 } & $\mathrm{E}$ & 63,89 & 63,89 & $\mathrm{~S}$ & & \\
\hline Rata - rata & 76,85 & 76,85 & $\mathrm{~T}$ & 66,08 & $\mathrm{~S}$ \\
\hline
\end{tabular}

Keterangan: $\mathrm{A}=$ Jumlah pertanyaan, $\mathrm{B}=$ Substansi pertanyaan, $\mathrm{C}=$ Bahasa,

$\mathrm{D}=$ Kesopanan $\mathrm{E}=$ volume, $\mathrm{K}=$ kategori

Berdasarkan Tabel.11 diketahui bahwa jumlah pertanyaan peserta didik kelas reguler berkategori kurang $(7,13 \%)$, untuk tata cara bertanya peserta didik berkategori sedang $(60,93 \%)$. Untuk kelas unggulan diketahui bahwa jumlah pertanyaan peserta didik berkategori sedang (48,14\%), untuk tata cara bertanya peserta didik berkategori tinggi (84,02\%) Tabel.12.

Terdapat beberapa indikator yang diukur pada tata cara bertanya peserta didik untuk kelas reguler yaitu pertama substansi pertanyaan yang diajukan peserta didik berkategori "sedang", yang kedua volume suara peserta didik ketika mengajukan pertanyaan berkategori "sedang", yang ketiga bahasa yang digunakan peserta didik ketika mengajukan pertanyaan berkategori "sedang", dan yang terakhir kesopanan peserta didik saat mengajukan pertanyaan berkategori "sedang". Untuk kelas unggulan yang pertama substansi pertanyaan yang diajukan peserta didik berkategori "tinggi", yang kedua volume suara peserta didik ketika mengajukan pertanyaan berkategori "sedang", yang ketiga bahasa yang digunakan peserta didik ketika mengajukan pertanyaan berkategori "tinggi", dan yang terakhir kesopanan peserta didik saat mengajukan pertanyaan berkategori "tinggi".

Pada pembelajaran fisika keterampilan bertanya peserta didik untuk kelas XI MIPA 1 berkategori kurang $(23,61 \%)$, XI MIPA 2 berkategori sedang $(68,05 \%)$, XI MIPA 3 berkategori kurang $(0 \%)$, XI MIPA 4 berkategori kurang $(23,61 \%)$ dan XI MIPA 5 berkategori sedang $(65,27 \%)$.

Kualitas pertanyaan peserta didik di SMA Negeri 2 Majene termasuk pertanyaan 
tingkat "rendah" hal ini terlihat dari jumlah pertanyaan tingkat kognitif rendah sedangkan pada pertanyaan tingkat kognitif tinggi peserta didik hanya mampu mengajukan satu pertanyaan. Untuk kelas XI reguler peserta didik laki-laki lebih banyak mengajukan pertanyaan dibandingkan dengan peserta didik perempuan (Tabel. 13). Untuk kelas XI unggulan perempuan lebih banyak mengajukan pertanyaan dibandingkan peserta didik laki-laki (Tabel. 14).

Tabel 13. Kualitas Pertanyaan Peserta Didik Berdasarkan Gender

\begin{tabular}{|c|c|c|c|c|c|c|c|}
\hline \multirow{2}{*}{\multicolumn{2}{|c|}{$\begin{array}{c}\text { Tingkat Ranah } \\
\text { Kognitif }\end{array}$}} & \multicolumn{4}{|c|}{ Jumlah Peserta Didik } & \multirow{3}{*}{$\begin{array}{l}\Sigma \\
\%\end{array}$} & \multirow{3}{*}{$\begin{array}{l}\Sigma \\
\%\end{array}$} \\
\hline & & \multicolumn{3}{|c|}{$\mathbf{L}$} & \multirow{2}{*}{$\begin{array}{l}\mathbf{P} \\
\% \\
\end{array}$} & & \\
\hline & & $\mathbf{n}$ & $\%$ & $\mathbf{n}$ & & & \\
\hline \multirow{3}{*}{$\begin{array}{c}\text { Ranah Kognitif } \\
\text { Tingkat } \\
\text { Rendah }\end{array}$} & $\mathrm{C} 1$ & 1 & 2,56 & 1 & 1,40 & 3,96 & \\
\hline & $\mathrm{C} 2$ & 5 & 12,82 & 1 & 1,40 & 14,22 & \\
\hline & $\mathrm{C} 3$ & - & - & - & - & - & \\
\hline \multirow{3}{*}{$\begin{array}{l}\text { Ranah Kognitif } \\
\text { Tingkat Tinggi }\end{array}$} & $\mathrm{C} 4$ & - & - & - & - & - & \\
\hline & $\mathrm{C} 5$ & - & - & - & - & - & - \\
\hline & C6 & - & - & - & - & - & \\
\hline \multicolumn{2}{|c|}{ Jumlah pertanyaan } & 6 & 15,38 & 2 & 2,80 & & \\
\hline
\end{tabular}

Tabel 14. Kualitas Pertanyaan Peserta Didik Berdasarkan Gender

\begin{tabular}{ccccc}
\hline Jumlah Peserta Didik & & $\Sigma$ & $\Sigma$ \\
\cline { 2 - 3 }$n$ & $\mathbf{P}$ & $\%$ & $\%$
\end{tabular}

Tingkat ranah kognitif

\begin{tabular}{|c|c|c|c|c|c|c|c|}
\hline & & $\mathbf{n}$ & $\%$ & $\mathbf{n}$ & $\%$ & & \\
\hline \multirow{2}{*}{$\begin{array}{l}\text { Ranah kognitif } \\
\text { tingkat rendah }\end{array}$} & $\mathrm{C} 1$ & 1 & 14,28 & 2 & 10 & 24,28 & \multirow{2}{*}{97,13} \\
\hline & $\mathrm{C} 2$ & 3 & 42,85 & 6 & 30 & 72,85 & \\
\hline
\end{tabular}

\begin{tabular}{ccccccc}
\cline { 2 - 7 } & $\mathrm{C} 3$ & - & - & - & - & - \\
\hline $\begin{array}{c}\text { Ranah kognitif } \\
\text { tingkat tinggi }\end{array}$ & $\mathrm{C} 4$ & - & - & 1 & 5 & 5 \\
\cline { 2 - 7 } & $\mathrm{C} 5$ & - & - & - & - & -
\end{tabular}

\begin{tabular}{rlllll}
\cline { 2 - 5 } C6 & - & - & - & - & - \\
\hline Jumlah pertanyaan & 4 & 57,13 & 8 & 45
\end{tabular}

Keterangan: $\mathrm{L}=$ Laki-laki $\mathrm{P}=$ Perempuan $\mathrm{n}=$ Jumlah peserta didik yang bertanya 
Hasil observasi kualitas pertanyaan peserta didik pada pembelajaran fisika kelas reguler menunjukan bahwa peserta didik laki-laki lebih banyak mengajukan pertanyaan dibandingkan peserta didik perempuan, serta peserta didik hanya mampu mengajukan pertanyaan pada ranah kognitif tingkat rendah. Sedangkan untuk kelas unggulan peserta didik perempuan lebih banyak mengajukan pertanyaan dibandingkan peserta didik laki-laki, serta peserta didik laki-laki hanya mampu mengajukan pertanyaan sampai ranah kognitif tingkat rendah sedangkan peserta didik perempuan sudah mampu mengajukan pertanyaan pada ranah kognitif tingkat tinggi. Jika dilihat dari keseluruhan kelas, peserta didik lebih banyak mengajukan pertanyaan pada ranah kognitif tingkat rendah yaitu C2 (Memahami).

Berdasarkan hasil analisis data yang telah dilakukan di kelas reguler, hasil penelitian menunjukan bahwa profil keterampilan bertanya peserta didik kelas reguler SMA Negeri 2 Majene pada semester ganjil tahun 2019 berkategori "rendah" dengan nilai rata-rata sebesar $34,03 \%$. Beberapa faktor yang mempengaruhi rendahnya Keterampilan bertanya peserta didik diantaranya metode pembelajaraan guru dan pemberian kesempatan bertanya saat pembelajaran berlangsung. Berdasarkan hasil observasi saat penelitian pada tanggal, 21 Agustus s.d 17 September 2019 terlihat bahwa metode pembelajaran yang dilakukan oleh guru adalah ceramah. Kekurangan metode ceramah menurut Limas Dodi guru sulit untuk mengetahui pemahaman anak didik terhadap bahan-bahan yang telah diberikan, kadang-kadang guru ingin menyampaikan bahan yang sebanyak-banyaknya hingga bersifat pemompaan, pemompaan adalah proses, cara, perbuatan memompa atau memompakan, anak didik cenderung lebih pasif dan kurang tepat mengambil kesimpulan. Akibatnya pembelajaran yang tercipta bersifat membosankan [7].

Selama proses pembelajaran guru kurang memberikan kesempatan kepada peserta didik untuk mengajukan pertanyaan, sehingga kesempatan bertanya menjadi terbatas. Pemberian kesempatan bertanya oleh guru ternyata tidak menyebabkan jumlah pertanyaan peserta didik yang tinggi. Jumlah pertanyaan yang diajukan oleh peserta didik rendah. Contoh kesempatan bertanya yang diberikan oleh guru setelah menyampaikan materi yaitu

"Ada yang ingin bertanya?"

Pemberian kesempatan pada contoh ternyata tidak membangkitkan minat peserta didik untuk bertanya, tetapi tetap ada peserta didik yang bertanya setelah diberikan kesempatan. Guru bertanya kepada peserta didik untuk mengetahui apakah peserta didik benar-benar paham dengan materi yang disampaikan atau belum.

Selama proses pembelajaran guru tidak memberikan apresiasi kepada peserta didik ketika bertanya. Apresiasi guru sangat berpengaruh terhadap jumlah pertanyaan. Menurut Sanjaya bahwa melalui keterampilan reinforcement yang pernah diberikan guru, peserta didik akan merasa terdorong untuk memberikan respon setiap kali muncul stimulus dari guru [10]. Dengan demikian fungsi keterampilan penguatan (reinforcement) itu akan meningkatkan partisipasi dan minat peserta didik dalam proses pembelajaran. Partisipasi peserta didik yang dimaksud dalam penelitian ini adalah keaktifan dalam mengajukan pertanyaan. 
Beberapa tata cara bertanya peserta didik pada pembelajaran fisika yaitu substansi pertanyaan, bahasa, volume suara dan kesopanan peserta didik dalam mengajukan pertanyaan. Tata bertanya peserta didik berkategori "sedang" dengan nilai rata-rata sebesar $(60,93 \%)$. Ketika guru memberikan kesempatan bertanya kepada peserta didik untuk bertanya, peserta didik bertanya sesuai dengan materi yang dijelaskan oleh guru mata pelajaran fisika.

Substansi pertanyaan yang sesuai dipengaruhi oleh perhatian peserta didik ketika guru memberikan materi, sehingga substansi pertanyaan peserta didik berkategori "sedang" dengan nilai rata-rata sebesar $(70,83 \%)$. Peserta didik mengajukan pertanyaan tentang materi yang baru dijelaskan oleh guru dan bersifat menggali informasi yang belum disampaikan oleh guru, walaupun ada beberapa peserta didik yang mengajukan pertanyaan yang bersifat mengulang kembali penjelasan guru. Sedangkan pada penelitian arif Muhammad Sebagian besar peserta didik sudah menyampaikan pertanyaan sesuai topik dan peserta didik dapat memahami pertanyaan yang disampaikan dengan baik [11].

Bahasa yang digunakan peserta didik ketika bertanya pada pembelajaran fisika berkategori "sedang" dengan nilai rata-rata sebesar $(56,25 \%)$. Peserta didik bertanya dengan menggunakan bahasa sehari-hari serta menggunakan kata tanya apa, siapa, kapan, dimana, mengapa, dan bagaimana $(5 W+1 H)$.

Contoh pertanyaan peserta didik dalam pembelajaran fisika adalah
a. Kenapa bisa nol?
b. Kenapa bisa nilai $R$ ada 2?
c. Bagaimana caranya mengetahui apa yang harus diintegralkan dan tidak diintegral?

Peserta didik menunjukan kesopanan saat bertanya berkategori "sedang" dengan nilai rata-rata sebesar $(58,33 \%)$. Hal tersebut terjadi karena ketika peserta didik mengajukan pertanyaan peserta didik langsung bertanya tanpa mengangkat tangan terlebih dahulu namun peserta didik sudah mengajukan pertanyaan ketika guru telah memberikan kesempatan kepada peserta didik untuk bertanya dan peserta didik menggunakan bahasa yang sopan ketika mengajukan pertanyaan.

Volume suara yang digunakan oleh peserta didik pada saat bertanya berkategori "sedang" dengan nilai rata-rata sebesar $(58,33 \%)$. Hal ini menunjukan bahwa peserta didik menggunakan volume suara yang cukup keras ketika bertanya sehingga guru dan sebagian besar peserta didik dapat mendengarkan pertanyaan dengan jelas.

Keterampilan bertanya peserta didik untuk semua kelas reguler masih berkategori rendah kecuali kelas XI MIPA 2 yang berkategori sedang. Royani berpendapat bahwa banyak peserta didik yang mengalami kesulitan untuk bertanya dan banyak yang lebih senang menunggu untuk menjawab pertanyaan daripada mempertanyakan sesuatu [1]

Untuk kelas XI Mipa 3 tidak ada peserta didik yang mengajukan pertanyaan selama proses pembelajaran. Salah satu dampak rendahnya keterampilan bertanya peserta didik adalah rendahnya hasil belajar. Hal ini sejalan dengan hasil penelitian yang dilakukan oleh Lamanepa dan Panis tahun 2018 Hasil penelitian menunjukan bahwa pertanyaan peserta didik menggambarkan sejauh mana kualitas berpikir dan tingkat pemahamannya pada materi fisika [9]. Lebih lanjut Meira Astuti mengulas tentang pentingnya kemampuan bertanya peserta didik dalam belajar mengungkapkan bahwa 
hasil belajar berkorelasi positif terhadap kemampuan bertanya yang baik [10].

Kualitas pertanyaan yang diajukan oleh peserta didik laki-laki dan perempuan tergolong kognitif tingkat "rendah". Hal ini terlihat dari jumlah pertanyaan tingkat kognitif rendah sebesar 18,18\%. Sedangkan pertanyaan kognitif tingkat tinggi tidak ada. Peserta didik hanya mampu mengajukan pertanyaan pada jenjang $\mathrm{C} 1$, dan $\mathrm{C} 2$. Sebagian besar peserta didik mengajukan pertanyaan pada jenjang $\mathrm{C} 1$ dan $\mathrm{C} 2$. Hal ini disebabkan karena metode pembelajaran yang dilakukan oleh guru. Metode pembelajaran ceramah yang digunakan hanya memunculkan pertanyaan pada tataran $\mathrm{C} 1$ dan $\mathrm{C} 2$. Bahkan peserta didik lainnya malah tidak tertarik dengan proses pembelajaran. Lebih lanjut hasil serupa dikemukakan Rizky Lestari kualitas pertanyaan peserta didik SMAN 1 Bandar Lampung masih berada pada kognitif tingkat rendah, dimana peserta didik hanya dapat mengajukan pada pertanyaan jenjang C4 [8].

Contoh pertanyaan yang diajukan oleh peserta didik selama proses pembelajaran berlangsung pada jenjang $\mathrm{C} 1$ adalah

\section{a. Tidak bisa pecahan nilainya ibu? \\ b. I nya momen inersia atau impuls?}

contoh pertanyaan jenjang C2 adalah

\section{a. Mengapa momen inersia pada gambar memiliki nilai 0 ?}

b. Bagaimana cara mengetahui apa yang harus diintegralkan dan tidak?

Pada pembelajaran fisika ternyata peserta didik laki-laki lebih banyak mengajukan pertanyaan dibandingkan dengan peserta didik perempuan. Jumlah peserta didik laki-laki yang bertanya sebesar $15,38 \%$ sedangkan untuk peserta didik perempuan hanya $2,80 \%$. Hal ini sejalan dengan Bastable yang menyatakan bahwa secara keseluruhan tidak ada perbedaan yang mencolok antara intelegensi umum anak laki-laki dan perempuan [6]. Jika ditinjau dari segi penyetaraan gender antara laki-laki dan perempuan sehingga menyebabkan peserta didik laki-laki lebih memiliki rasa ingin tahu yang besar dibandingkan dengan perempuan. Beberapa peserta didik kurang berani dan tidak percaya diri untuk bertanya dikarenakan pengaruh lingkungan seperti takut salah dan takut mendapat ejekan.

Sementara untuk kelas unggulan menunjukan bahwa profil keterampilan bertanya peserta didik berkategori "sedang" dengan nilai rata-rata sebesar $66,08 \%$. Selama proses pembelajaran guru menuntut peserta didik untuk aktif bertanya. Hal ini dilihat dari jumlah pertanyaan yang diajukan oleh peserta didik berada pada kategori sedang (48,14\%). Guru memberikan apresiasi kepada peserta didik yang bertanya. Bentuk apresiasi yang diberikan oleh guru contohnya:

\section{"ya.... pertanyaannya sangat bagus"}

Tata cara bertanya peserta didik kelas unggulan berkategori tinggi $(84,02 \%)$. Substansi pertanyaan yang diajukan oleh peserta didik berkategori tinggi (100\%). Peserta didik mengajukan pertanyaan tentang materi yang baru saja dijelaskan oleh guru. Pertanyaan tersebut bersifat menggali informasi yang belum disampaikan oleh guru. Bahasa yang digunakan peserta didik berkategori tinggi (94,44\%). Peserta didik mengajukan pertanyaan menggunakan bahasa baku serta menggunakan kata tanya $5 \mathrm{~W}+1 \mathrm{H}$. 
Kesopanan peserta didik berkategori tinggi (77,78\%). Peserta didik mengajukan pertanyaan ketika guru telah memberikan kesempatan bertanya kemudian peserta didik mengangkat tangan dan menggunakan bahasa yang sopan saat mengajukan pertanyaan. Sedangkan untuk volume suara berkategori sedang $(63,89 \%)$. Peserta didik mengajukan pertanyaan yang cukup keras sehingga guru dan sebagian besar peserta didik mendengarkan pertanyaan dengan jelas.

Kualitas pertanyaan yang diajukan oleh peserta didik laki-laki dan perempuan masih tergolong ranah kognitif tingkat "rendah". Hal ini terlihat dari jumlah pertanyaan tingkat kognitif rendah sebesar 97,13\%, sedangkan untuk ranah kognitif tingkat tinggi peserta didik perempuan sudah mengajukan pertanyaan walaupun hanya 5\%. Peserta didik perempuan lebih banyak mengajukan pertanyaan dibandingkan laki-laki. Penyetaraan gender antara laki-laki dan perempuan menyebabkan peserta didik perempuan tidak sungkan dalam mengutarakan gagasannya. Selain itu, perempuan cenderung menggunakan sisi kiri dan sisi kanan otaknya secara keseluruhan sehingga pengelolaaan bahasanya lebih baik menurut Bastable [6].

Pertanyaan peserta didik di kelas ini didominasi oleh pertanyaan kognitif tingkat rendah yaitu C1 dan C2. Dengan demikian dapat dikatakan sebagian besar peserta didik di kelas XI MIPA 5 memiliki kemampuan bertanya ranah kognitif rendah. Walaupun sudah ada peserta didik yang mampu mengajukan pertanyaan pada jenjang C4 namun, hanya satu pertanyaan yang mampu diajukan. Sementara jika ditinjau dari jenjang pendidikan, peserta didik pada tingkatan SMA semestinya telah mampu mengaplikasikan keterampilan kognitif tingkat tinggi. Karena menurut Piaget peserta didik pada level SMA berada pada tahap operasional formal. Tahap operasional formal merupakan tahapan dimana peserta didik mempunyai kemampuan untuk berpikir secara abstrak [9].

\section{SIMPULAN DAN SARAN}

\section{Simpulan}

Berdasarkan hasil penelitian dan pembahasan, maka dapat disimpulkan bahwa Keterampilan bertanya peserta didik dalam pembelajaran fisika di SMA Negeri 2 Majene kelas reguler berkategori "rendah", dengan jumlah pertanyaan berkategori "kurang" dan tata cara bertanya berkategori "sedang". Sedangkan, untuk kelas unggulan keterampilan bertanya peserta didik berada pada kategori "sedang", dengan jumlah pertanyaan berkategori "sedang" dan tata cara bertanya berkategori "tinggi". Kualitas pertanyaan peserta didik kelas reguler dan kelas unggulan masih berada pada ranah kognitif tingkat rendah. Pada kelas reguler peserta didik laki-laki lebih banyak mengajukan pertanyaan dibandingkan dengan peserta didik perempuan. Sedangkan, untuk kelas unggulan peserta didik perempuan lebih banyak mengajukan pertanyaan dibandingkan peserta didik lakilaki.

\section{Saran}

Adapun saran yang diberikan peneliti yaitu:

1. Sebaiknya untuk kelas reguler dan unggulan membiasakan mengajukan pertanyaan pada ranah kognitif tinggi.

2. Sebaiknya guru tidak menggunakan lagi metode ceramah agar peserta didik lebih aktif untuk mengajukan pertanyaan.

3. Sebaiknya sebelum mengajukan pertanyaan peserta didik mengangkat 
tangan terlebih dahulu sebelum mengajukan pertanyaan.

4. Dalam penelitian deskriptif diperlukan tambahan observer agar peneliti tidak merasakan kesulitan untuk menemukan fakta-fakta yang terjadi di lapangan

5. Untuk peneliti selanjutnya sebaiknya mempersiapkan alat perekam dengan kualitas yang lebih baik untuk mengambil dokumentasi berupa foto dan vidio selama pembelajaran berlangsung

\section{DAFTAR PUSTAKA}

[1] Royani, M, dkk. 2014. keterampilan bertanya siswa smp melalui strategi pembelajaran aktif tipe team quiz pada materi segi empat. Jurnal Pendidikan Matematika, Volume 2, No.1

[2] Asmara, j, dkk. 2016. Aliansi permasalahan guru terkait pengembangan perangkat pembelajaran berbasis model think talk write (TIW) dan permasalahan siswa terkait keterampilan bert anya siswa dalam pembelajaran biologi. Jurnal pendidikan. Vol.1, No.1, EISSN: 2502$471 \mathrm{X}$

[3] Widodo, A. 2006, Profil Pertaynaan Guru Dan Siswa Dalam pembelajaran Sains. Jurnal Pendidikan dan Pembelajaran. 4(2), 139-148

[4] Ramadhan, F, dkk, 2017, Kemampuan Bertanya Siswa Kelas X SMA Swasta Kota Batu pada Pelajaran Biologi. Jurnal Pendidikan Biologi, ISSN 24429805, (Vol. 8 NO. 1)

[5] Nuraini, fitri, dkk. 2017. Profil keterampilan bertanya siswa pada pembelajaran Biologi SMAN 2 Bandar Lampung. Jurnal bioterdidi, Volume 5,No.4

[6] Yuliani. 2015. analisis kualitas pertanyaan siswa berdasarkan gender dan taksonomi bloom. Jurnal bioterdidik vol.3, No1

[7] Dodi, limas. 2013. metode pengajaran nahwu shorof. jurnal penelitian dan kajian keislaman, Volume.1,No.1

[8] Lestari, Rizky. 2017. Profil keterampilan bertanya siswa pada pembelajaran biologi sman 1 bandar lampung, Vol.5 No.4.

[9] Lamanepa, G, H, \& Panis, I, C, 2018. Peningkatan Kemampuan Bertanya dan Pemecahan Masalah Peserta Didik SMA dalam Pembelajaran Fisika Melalui Problem Based Learning

[10]Astuti, Meiria Sylvi. 2015. Peneningkatan keterampilan bertanya dan hasil belajar siswa kelas 2 sdn slungkep 03 menggunakan model discovery learning. Jurnal Scholaria, Vol. 5, No. 1

[11] Arif, muhammad. 2016. peningkatan kemampuan bertanya melalui debat aktif siswa kelas vlll $d$ smp $n \quad 2$ banuntapan bantul. Jurnal Prodi Teknologi Pendidikan Vol. V Nomor 5 